\title{
Rehabilitation needs for older adults with stroke living at home: perceptions of four populations Claude Vincent*1,2, Isabelle Deaudelin ${ }^{1}$, Line Robichaud ${ }^{2}$, Jacqueline Rousseau ${ }^{3,7}$, Chantal Viscogliosi ${ }^{4}$, Lise R Talbot ${ }^{4,5}$, Johanne Desrosiers ${ }^{4,6}$ for other members of the BRAD group
}

\begin{abstract}
Address: ${ }^{1}$ Centre for Interdisciplinary Research in Rehabilitation and Social Integration (CIRRIS), Institut de réadaptation en déficience physique de Québec, 525, Wilfrid-Hamel Blvd East, Québec (Québec), G1M 2S8, Canada, ²Département de réadaptation, Université Laval, Pavillon Ferdinand-Vandry, Québec (Québec), G1K 7P4, Canada, 'École de réadaptation, Université de Montréal, Pavillon Marguerite D'Youville, c.p. 6128, succursale Centre-ville, Montréal (Québec), H3C 3J7, Canada, ${ }^{4}$ Research Centre on Aging, University Institute of Geriatrics of Sherbrooke, 1036 Belvédère South, Sherbrooke (Québec), J1H 4C4, Canada, ${ }^{5}$ Department of Nursing, Faculty of Medicine and Health Sciences, Université de Sherbrooke, 3001, 1st Avenue, Sherbrooke (Québec), Canada, ${ }^{6}$ Department of Rehabilitation, Faculty of Medicine and Health Sciences, Université de Sherbrooke, 3001, 12th Avenue, Sherbrooke (Québec), Canada and ${ }^{7}$ Research Center on Aging, University Institute of Geriatrics of Montreal, 4564 Queen Mary Road, Montréal (Québec), H3W 1W5, Canada
\end{abstract}

Email: Claude Vincent* - claude.vincent@rea.ulaval.ca; Isabelle Deaudelin - isabelle.deaudelin@rea.ulaval.ca; Line Robichaud - line.robichaud@rea.ulaval.ca; Jacqueline Rousseau - jacqueline.rousseau@umontreal.ca; Chantal Viscogliosi - chantal.viscogliosi@USherbrooke.ca; Lise R Talbot - lise.talbot@USherbrooke.ca; Johanne Desrosiers - johanne.desrosiers@USherbrooke.ca

* Corresponding author

Published: 13 August 2007

BMC Geriatrics 2007, 7:20 doi:10.1/86/147/-2318-7-20
Received: II October 2006

Accepted: 13 August 2007

This article is available from: http://www.biomedcentral.com/I47|-23/8/7/20

(c) 2007 Vincent et al; licensee BioMed Central Ltd.

This is an Open Access article distributed under the terms of the Creative Commons Attribution License (http://creativecommons.org/licenses/by/2.0), which permits unrestricted use, distribution, and reproduction in any medium, provided the original work is properly cited.

\begin{abstract}
Background: Many people who have suffered a stroke require rehabilitation to help them resume their previous activities and roles in their own environment, but only some of them receive inpatient or even outpatient rehabilitation services. Partial and unmet rehabilitation needs may ultimately lead to a loss of functional autonomy, which increases utilization of health services, number of hospitalizations and early institutionalization, leading to a significant psychological and financial burden on the patients, their families and the health care system. The aim of this study was to explore partially met and unmet rehabilitation needs of older adults who had suffered a stroke and who live in the community. The emphasis was put on needs that act as obstacles to social participation in terms of personal factors, environmental factors and life habits, from the point of view of four target populations.
\end{abstract}

Methods: Using the focus group technique, we met four types of experts living in three geographic areas of the province of Québec (Canada): older people with stroke, caregivers, health professionals and health care managers, for a total of 12 groups and 72 participants. The audio recordings of the meetings were transcribed and NVivo software was used to manage the data. The process of reducing, categorizing and analyzing the data was conducted using themes from the Disability Creation Process model.

Results: Rehabilitation needs persist for nine capabilities (e.g. related to behaviour or motor activities), nine factors related to the environment (e.g. type of teaching, adaptation and rehabilitation) and II life habits (e.g. nutrition, interpersonal relationships). The caregivers and health professionals identified more unmet needs and insisted on an individualized rehabilitation. 
Older people with stroke and the health care managers had a more global view of rehabilitation needs and emphasized the availability of resources.

Conclusion: Better knowledge of partially met or unmet rehabilitation needs expressed by the different types of people involved should lead to increased attention being paid to education for caregivers, orientation of caregivers towards resources in the community, and follow-up of patients' needs in terms of adjustment and rehabilitation, whether for improving their skills or for carrying out their activities of daily living.

\section{Background}

Stroke is the third leading cause of long-term disability [1] and its incidence increases markedly with advancing age [2]. With improvements in health care, more people survive strokes but many have to cope with the physical, psychological, social and functional sequelae, resulting in increased personal and public costs $[1,3-5]$ and a marked decline in their quality of life [6-11]. After a stroke, most elderly people return to their home environment quickly, despite suffering from various impairments and disabilities and often without having received any rehabilitation services to reduce or compensate them $[12,13]$. In Canada, only about 10 to $15 \%$ of people with stroke receive inpatient rehabilitation services [14]. The other survivors, whose physical deficits are not so severe or whose impairments and disabilities are not properly identified, return to their own environment, with or without support services $[15,16]$. In order to better plan the offer and delivery of rehabilitation services, the partially met or unmet needs of people who live at home after stroke are little known, especially from the perspective of the different actors involved in this process. Even though many studies have been carried out on recovery from impairments and disabilities after stroke and the consequences of such disabilities, very few are interested in exploring partially met and unmet rehabilitation needs that could restrict the social participation of these people in their daily activities and social roles.

The aim of this study was to explore partially met and unmet needs of adults aged 65 years or over who had suffered a stroke and who live in the community, with or without services. The emphasis was put on the needs that are considered obstacles to social participation from the point of view of older adults with stroke, caregivers, health professionals and health care managers.

\section{Literature review}

What do we know about social participation and rehabilitation needs for people with stroke?

\section{Social participation}

According to the Disability Creation Process (DCP) model, social participation or its opposite, handicap situation, is identified as a situational result that varies over time depending on the interaction between personal factors (the individual's organic system, capabilities, identity) and environmental factors (social and physical) $[17,18]$ (Figure 1). This systemic model of human development, which is widely known and used in Canada, is based on the interaction between individuals and their environment. This model is very useful for identifying and classifying variables under study with greater systematization and consistency.

Stroke highly affects personal factors that include both impairment and disability. There is major impairment of the nervous system and other organic systems (e.g., muscular, ocular). The consequences of these impairments are operationalized through the presence of disabilities in capabilities (e.g., intellectual, language, behaviour, sense and perception, motricity and balance). Depending on the number and extent of these disabilities, people vary in their ability to accomplish daily activities and social roles (presence of handicap situations at one end of the spectrum and optimal social participation at the other) [19].

The characteristics of the person's environment also affect social participation after stroke. Social environmental factors include elements such as the support from the family and utilization of health and social services, whereas physical environmental factors refer to natural or technological elements (e.g., climate, technical aids). As obstacles or facilitators, these factors can either hinder or help in the accomplishment of daily activities and social roles.

Finally, the different activities and roles that the person values (called 'life habits' in the model) are divided into 12 domains. Six of these domains refer to the person's daily activities (nutrition, fitness, personal care, communication, housing, mobility) whereas the other six refer to social roles (responsibility, interpersonal relationships, community life, education, employment, recreation). It is in these activities and roles that handicap situations or restriction of participation can arise. In the DCP model, needs might be considered as the outcome of a lack of congruence between personal factors and different factors in the environment [18]. 


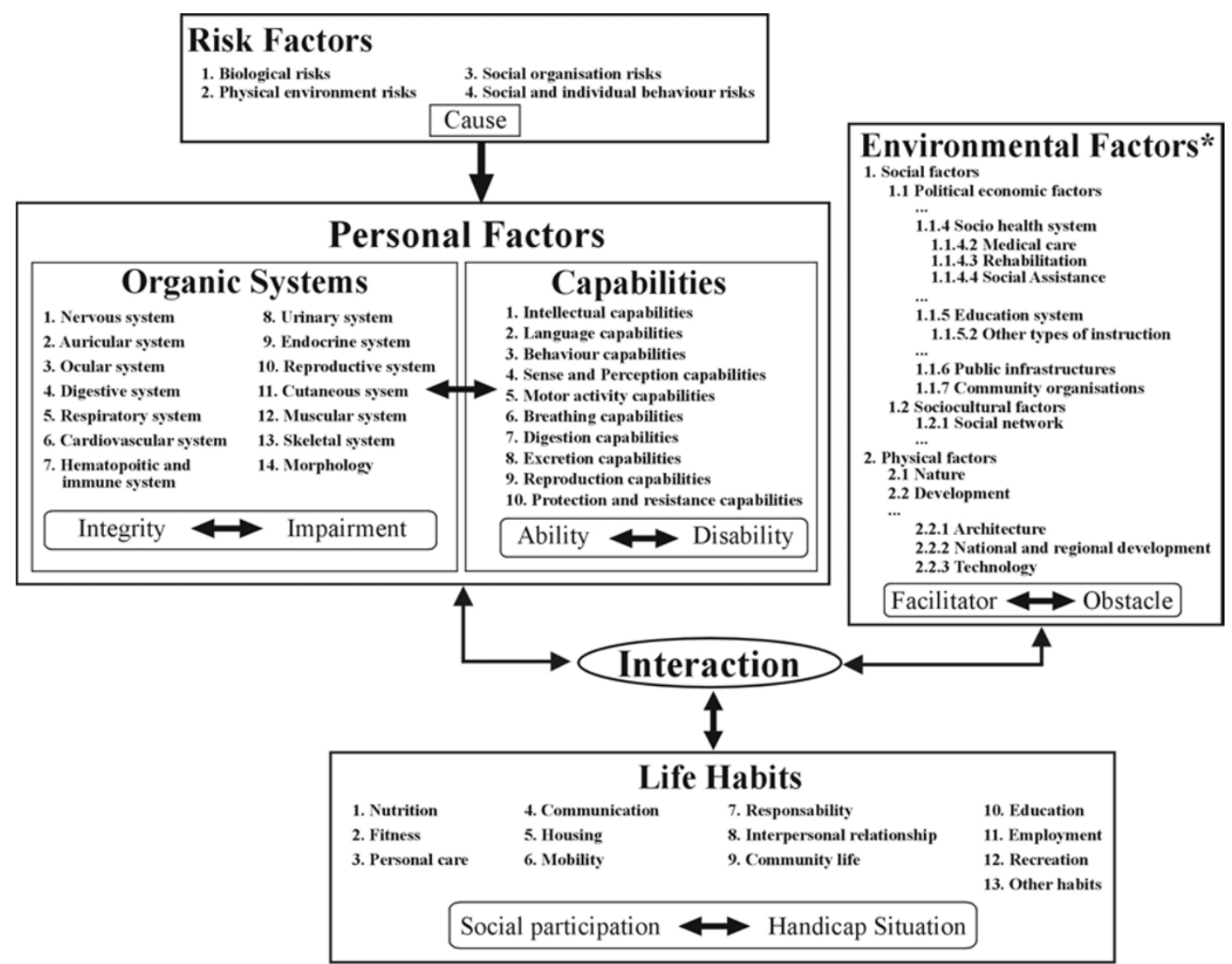

Figure I

The Disability Creation Process, conceptual scheme (Fougeyrollas, Cloutier, Bergeron, Côté, Côté \& St-Michel, 1998). CRIPPH 1998. ripph@irdpq.qc.ca. I(4I8)529-9I4I, p.6202. *Authors of this manuscript have added subcategories to the original scheme to facilitate the understanding of text.

Because of the high incidence of stroke [20] and its potentially negative impact on various aspects of a patient's life [5,10,21-23], studies on social participation were carried out among people who had suffered a stroke. The results of a telephone survey conducted by Mayo et al. in 2002 [24] among 434 respondents show that participation by this clientele in basic activities such as eating, dressing and moving around is less often restricted (39\%) than participation in domestic tasks such as going shopping and cleaning the house (54\%) which, in turn, is less affected than participation in community activities (65\%) associated with social roles.

\section{Rehabilitation needs}

Specific studies on rehabilitation needs are still rare $[15,22,25-28]$, which means that generic literature on needs is applied to rehabilitation. Bradshaw's taxonomy of social need [29], as used by Pineault and Daveluy [30], identifies four types of needs: felt, expressed, normative and comparative. Felt needs are equated with wants and are limited by the perceptions of the individuals in regard to the health services available [29]. Expressed needs are demands or felt needs turned into action. They are commonly used in health care services where waiting lists are taken as a measure of unmet need [29]. Normative needs are those defined by health professionals, administrators or experts in relation to norms or a desirable standard [29]. Finally, comparative needs refer to a measure established by studying the characteristics of those in receipt of a service, in other words, populations in which the evaluated needs are generalized [29].

The goals of rehabilitation services and programs are currently based on the judgment of professionals who evalu- 
ate functional disabilities, ability to carry out daily activities and significant leisure, occupational and social activities, as well as health problems [31], to determine needs. These needs assessments are often incomplete because assessments are done only once, most often with standardized tests and outside the person's home environment or community context $[15,16,32]$. Furthermore, although family members may have more difficulty identifying needs than the patients themselves and the professionals [33], their input is essential to a needs assessment $[16,34,35]$. Consideration both of the needs expressed by individuals and their caregivers, and of the normative needs identified by health professionals, ensures a more reliable result, since many patients can be more passive than expected in expressing their needs [25,32,36-39]. Also, expressed needs for rehabilitation services may greatly vary from one area to another $[27,40-42]$, possibly because of differences in accessibility. In addition, repeated measures post-stroke show that needs change over time $[14,28,38,43]$.

Based on the DCP model, there are needs related to personal factors (capabilities) [9]. Indeed, motor and sensory problems on the side contralateral to the brain lesion $[12,14,16,44,45]$ as well as perceptual and cognitive [14,47-51] and psychosocial [14,40,46,49-59] disorders, disrupt the daily lives of people with stroke. Often, older adults with stroke do not spontaneously find effective strategies to cope with the affective (apathy, depression, emotional variation) and cognitive problems (memory, attention, concentration, organization, judgment, communication) [60-62]. Even after adjusting for the degree of physical disability, people with cognitive deficits remain more dependent, and this dependence has increased two years after the stroke [49]. In a study carried out in Denmark, the patients reported the need for supervision and advice to continue proper physical and cognitive training at home [63]. Martin et al. (2002) [19] and Pierce et al. (2004) [64] presented similar outcomes in their recent works.

Some needs related to environmental factors are documented in literature but most of them refer mainly to rehabilitation services and education, without considering other important environmental elements. Following inpatient rehabilitation, people who had suffered a stroke expressed unmet needs related to preparation for discharge, instructions, information and support with referrals to community resources, rehabilitation services, exercise programs at home, support in doing exercise programs, support for the individual and couple during the adaptation process, nutrition, safety and housework [55,60,65-68]. The optimum benefit from rehabilitation is often not achieved during hospitalization, because of the stress experienced in the acute phase $[11,59]$. Thus, there is a perceived lack of care continuity [23,41,69]; one of the aims of the single entry point, which is currently being implemented in some regions, is to fill this gap [70]. During the rehabilitation process, some individuals progress more slowly and may need treatment to improve recovery for up to two years post-stroke $[43,71,72]$. Education, combined with counselling for self-assessment, could help people become more aware of their needs, which would help them adjust better to their disabilities $[27,73]$. Rehabilitation should focus more on satisfaction with life and leisure activities than simply on independence in day-to-day activities $[5,32,62]$. Brandriet and colleagues [60] studied perceived needs post-stroke after discharge from inpatient rehabilitation among a small number of individuals $(\mathrm{n}=20)$ in a single metropolitan area; post-stroke survivors indicated they needed more therapy (physical therapy, occupational therapy and speech therapy) whereas they and caregivers also reported the need for greater social support. The recent focus group study of Hare et al. [72] combined two groups of experts (27 patients and 6 caregivers). The study concluded that better methods were required for providing information to long-term survivors of stroke and for addressing their emotional and psychological needs $[22,46]$. As mentioned earlier, literature concerning other types of needs related to environmental factors is limited. In one example, Evans and Northwood [73] carried out a study among a heterogeneous population aged 43 to 87 years; one of their conclusions was that there exist social assistance needs for adjustment to stroke.

For needs related to life habits, the third component of the DCP model, most of the previous studies point out general problems with mobility and instrumental activities of daily life [46,60-62,74]. In the Brandriet et al.'s study [60], post-stroke survivors indicated specific unmet needs for housekeeping, financial, nutritional and safety aspects as well as for relearning skills (maintenance/household tasks). Between one and four years post-stroke, balance, walking and instrumental activities of daily life such as personal care, housekeeping, cooking and psychosocial activities have deteriorated $[11,75]$.

The present group of authors had previously carried out a preliminary study with four different small groups of experts (patients, caregivers, health professionals and health care managers) from a single semi-urban area [76]. Results showed partial and unmet needs relating to personal factors (mainly capabilities), environmental factors and life habits. Analysis of environmental factors also revealed the need for social support, the need for more rehabilitation services and the importance of the caregiver's role. Results were sufficiently relevant to motivate a more in-depth study in different socio-geographic areas including urban and rural areas. 
In summary, context of all of the above studies was restricted, which limits their external validity. Most literature considers capabilities, the socio-health system, the education system and some life habits (daily activities); there is very little information about unmet rehabilitation needs related to social roles and environmental factors such as social assistance, public infrastructures, community organizations, social network and physical factors. Also, most of the literature refers to normative needs (from the health professionals' perspective). In 2002, when our study began, very few studies put emphasis on expressed needs from the standpoint of older adults with stroke and caregivers. After 2004, studies were published on that subject $[32,34,37,38,77,82]$. We could not find any literature written from a health care manager's perspective except for Talbot et al. [76], our pilot study. Since most people report a reduction in their activities and interests post-stroke [74], stroke has a substantial impact on the accomplishment of daily activities and social roles (life habits) that are essential to well-being and personal development, even when impairment and disability are mild [10].

\section{Objective of the study}

This study examined partially met and unmet rehabilitation needs (expressed and normative) for people with stroke aged 65 and over, with respect to their personal factors (capabilities) and life habits, and environmental factors, with a view to maintaining optimal social participation. Better knowledge and understanding of rehabilitation needs and services for this population should contribute to changes in clinical and organizational practices.

\section{Methods \\ Design}

The study, conducted in 2005, followed a cross-sectional design using the focus group technique [78], individual interviews and a qualitative analysis strategy $[79,80]$.

\section{Sample and eligibility criteria}

To enhance the transferability $[80,81]$ of results, this study was conducted in three regions of the province of Quebec: Montreal (metropolitan area : 1873813 people, 3671,3 per $\mathrm{km}^{2}, 15 \%$ over 65 years old), Eastern Townships: (rural area : 300383 people, 29,5 per km², 14,4\% over 65 years old) and Chaudière-Appalaches (rural area: 396171 people, 26,3 per km², $13.8 \%$ over 65 years old). In Canada (30000000 people), there are over 50,000 strokes each year - including 16,000 deaths. Four target populations were identified: 1) older people with stroke, hereinafter called 'patients', 2) family caregivers, 3) health professionals, and 4) health care managers involved in the rehabilitation of older adults. Caregivers and stroke survivors were independent of each others. The patients and family caregivers were recruited through support groups for people who had suffered a stroke, such as stroke clubs or community home services centres. Specific criteria (theoretical sampling) were defined, such as various levels of disabilities, gender, and different ages, in order to capture different experiences. The health professionals and the health care managers came from various clinical, institutional and community environments providing rehabilitation services to older adults. The health professionals were recruited through professional service coordinators, who were contacted by phone after receiving a letter explaining the research project. The health care managers were recruited through the regional health and social service boards in the three study regions.

For the eligibility criteria, the patients had to: a) have had at least one stroke, with the most recent occurring after the age of 65 and the previous at least two years earlier b) be living at home, and c) be able to verbally express their needs. Three quarters of people who had a stroke are aged over 65 years and, in Canada, specific health care programs are offered to this clientele, justifying the age criterion. We excluded people affected by other limitative neurological, sensory, musculoskeletal or chronic diseases, to avoid confusion between the needs related to these diseases and the needs associated with stroke. The caregivers had to: a) be the informal (family) caregiver for at least one year of a person with stroke who meets the above criteria, b) provide at least two hours of help per week, and c) be 18 years or older. The health professionals had to have at least two years' experience in an environment providing services to older adults with stroke. Finally, the health care managers had to come from the rehabilitation settings specified above. All participants should have been able to express themselves in French.

\section{Focus group technique and individual interviews}

Focus groups were organized in each region, with patients, family caregivers, health professionals and health care managers, for a total of 12 groups (4 populations $\times 3$ regions). The meetings lasted approximately two hours each and were recorded on audiotape. A moderator, an assistant moderator and an observer (researcher) were present at each group meeting. The same research team attended the meetings in all three regions. Focus group interview guides, refined after the pilot study, are presented in Talbot et al.'s paper [76]. To ensure the group meetings ran smoothly and generated the best content, 45 participants were sought for each group of patients and caregivers, and 7-8 participants were expected for each group of health professionals and health care managers [78].

In addition, to capture a wider variety of experience related to the needs expressed, 4 individual interviews 
with patients and caregivers were conducted, since some participants were not able to participate in the focus group meetings for various reasons (reduced mobility, uncomfortable in a group situation, caregiver unavailable).

\section{Data analysis strategy and conceptual framework}

The focus group participants' profile was described in terms of age, gender and other relevant characteristics, depending on the group. The audiotape of the content of each group $(n=12)$ and during interviews $(n=4)$ was transcribed, then coded, recoded and classified. NVivo software (v.2) was used to manage the data. The analysis process was systematic and rigorous and respected scientific criteria for qualitative research $[79,80]$. An initial classification of the data was based on the Disability Creation Process presented earlier. All the transcriptions were recoded by the groups' researchers to validate the process of coding, i.e. the accuracy of the theoretical classification and the emerging classification themes. Disagreements were discussed (30\% of the codification) and decisions reached by consensus to finally converge on emerging themes that made sense and which accurately reflected the content of the discussions. Data were analyzed considering two aspects: 1) For each type of group, we calculated iterations for each theoretical theme (the number of times a participant discussed a specific theme); 2) For the content, we created emerging themes reflecting the discussions and classified them under the theoretical aspect.

\section{Results}

\section{Participants' profile}

In all three regions, 17 persons with stroke and living at home took part in individual interviews $(\mathrm{n}=3)$ and focussed discussion groups $(\mathrm{n}=14)$ (Table 1). Their age varied between 65 and 85 years. Most had had their stroke over two years previously and were living alone or with their spouse. Patient's profile meets the specific criteria "various levels of disability representation" because less than one third were receiving home care assistance from the public health care system, while over half were being cared for informally by their next of kind. Also, three patients with more severe limitations were met at home. The patients' educational level varied.

Twelve close caregivers aged between 41 and 69 participated in focussed discussion groups $(\mathrm{n}=11)$ and one individual interview $(\mathrm{n}=1)$ (Table 2). In general, the caregivers interviewed were assisting people who were more severely disabled than the patients recruited to participate in the focus groups for persons with stroke. They were either the spouse or the daughter of the person for whom they had been caring for at least one year, from two to twenty hours per week in various ways. Most of the caregivers were retired.
Twenty-five health professionals participated in the discussion groups (Table 3 ). They had more than nine years of clinical experience. They were working in six different areas of intervention and represented nine professional disciplines.

Finally, 18 health care managers took part in the discussion groups (Table 4). They came from seven different practice areas; two-thirds had clinical experience with stroke patients. Eight of them had over 10 years' management experience (see Table 4).

\section{Needs related to personal factors (capabilities)}

Nine categories of capabilities were documented out of a possibility of 10 listed in the DCP model [18]. In fact, only the "breathing capabilities" category was not discussed by participants. The themes that emerged for each category are presented in Table 5. The capabilities that drew the most interest in terms of partially met or unmet needs were those related to behaviour, language, motor activities and sexual relations. The caregivers were especially sensitive to behavioural changes in the patient, which was also the case for the health professionals, though to a lesser extent. The health care managers were particularly sensitive to the needs related to language capabilities, while the patients themselves seemed more affected by partial or unmet needs relating to motor activities, such as walking and gripping ability, as well as more intimate activities such as sexual relations. However, Table 5 shows four categories of capabilities that were not identified as partial or unmet needs by the patients and three that were not identified as such by the health care managers.

\section{Needs related to environmental factors}

Table 6 presents the themes emerging for each environmental factor of the DCP model, according to the order shown in Figure 1. Four politico-economic factors were documented out of a possible seven: socio-health system (medical care, rehabilitation, social assistance), education system (other types of instruction), public infrastructure and community organizations. Needs related to the political system and governmental structure, the judicial system or the economic system were not reported by any of the participants. One of the two sociocultural factors of the model was explored. Social rules were not addressed by the participants. Finally, some physical elements were discussed.

\section{Socio-health system}

At the medical care level, all the groups agreed on needs relating to financial and human resources (scarcity of resources), and most participants talked of difficulty accessing the services (delays and disparities) and obtaining follow-up. Partially met or unmet needs were reported 
Table I: Description of characteristics of people with stroke

\begin{tabular}{|c|c|c|c|}
\hline Patients (N = I7) & $\begin{array}{l}\text { Eastern Town- } \\
\text { ships }(\mathrm{n}=\mathbf{8})^{\prime}\end{array}$ & $\begin{array}{c}\text { Montreal }(\mathrm{n}= \\
\text { 3) }\end{array}$ & $\begin{array}{l}\text { Chaudières- } \\
\text { Appalaches (n } \\
=6)\end{array}$ \\
\hline \multicolumn{4}{|l|}{ Age: } \\
\hline $65-75$ years & 4 & I & 5 \\
\hline $76-85$ years & 4 & 2 & 1 \\
\hline Gender (M) & 5 & 0 & 5 \\
\hline Living environment (urban) & 3 & 3 & 3 \\
\hline \multicolumn{4}{|l|}{ Time elapsed since stroke: } \\
\hline$<1$ to 3 years & 4 & I & 4 \\
\hline $4-8$ years & 4 & 1 & 2 \\
\hline 9 years and + & 0 & 1 & 0 \\
\hline \multicolumn{4}{|l|}{ Education level: } \\
\hline Elementary & 6 & I & 2 \\
\hline Secondary & 2 & I & 3 \\
\hline Post-secondary & 0 & 1 & 1 \\
\hline Registered for public home care services & 2 & 1 & 2 \\
\hline Receive assistance from relatives or friends & 5 & 3 & 3 \\
\hline
\end{tabular}

Note I In this region, 3 patients were interviewed individually.

at several levels of rehabilitation. For ease of understanding in Table 6 , all the interventions aimed at improving a person's potential were classified under "rehabilitation", while those concerning adjustment to the human and physical environment were classified under "adjustment". Adjustment becomes necessary when an individual's rehabilitation has reached a plateau; at that stage the individual's disabilities must be compensated by the human or physical environment [82]. The themes arising from the discussions indicate that rehabilitation is not often personalized to the needs of the patient and that, for reasons of budget and availability of resources, the emphasis is put more on evaluating patients than on rehabilitation activities. Lack of resources in psychology, speech therapy and neuropsychology was also reported. On the issue of adjustment, the caregivers and health professionals exposed a number of problems relating to services for adapting the patient's home or vehicle and with respect to obtaining technical assistance. In addition to the disparities and delays in the various services, there are also persistent problems in the continuity of these services. Furthermore, on the issue of adjustment, not enough support is given to patients and caregivers to identify the resources available to them in the community. Finally, the psychosocial support offered to families who are in the process of rehabilitation is not necessarily available at the right time. To sum up the needs with respect to the socio- health system, social assistance emerges as an unmet need that is criticized by many. Access to support groups for caregivers, sitting and respite services and temporary lodging remain unmet needs expressed by many participants.

Regarding the education system, with respect to other types of instruction (not related to academics), there is a pressing need to educate caregivers and to give the instruction at the right time. The need for education was discussed in all the groups and to a greater degree among the health professionals. Insofar as public infrastructure is concerned, only the need for accessible/adapted transportation or paratransit was described as being partially met or unmet. The issue of community resources was hardly raised at all; this appeared to be a little known subject by all the groups of participants. Finally, with respect to support from community organizations, the caregivers and health professionals were the two main groups who expressed concerns about needs in this area.

\section{Sociocultural factors}

Just one sociocultural factor was discussed: the social network. This aspect remains an unmet need that was identified unanimously by the caregivers, health professionals and patients alike. The main points raised concerned relations with family, friends and organizations promoting awareness in the community. 
Table 2: Description of characteristics of close caregivers

\begin{tabular}{|c|c|c|c|}
\hline Caregivers $(N=12)$ & Eastern Townships $(n=6)^{\prime}$ & Montreal $(n=3)$ & $\begin{array}{c}\text { Chaudières- } \\
\text { Appalaches }(n=3)\end{array}$ \\
\hline \multicolumn{4}{|l|}{ Age: } \\
\hline $4 I-59$ years & 4 & 1 & 0 \\
\hline $60-69$ years & 2 & 2 & 3 \\
\hline Gender (F) & 5 & 3 & 1 \\
\hline Living environment (urban) & 2 & 3 & 2 \\
\hline \multicolumn{4}{|l|}{ Current occupation: } \\
\hline Works outside the home & 2 & 2 & 1 \\
\hline Retired & 4 & 1 & 2 \\
\hline Relationship with patient: & & & 3 \\
\hline Spouse & 5 & 2 & \\
\hline Daughter & 1 & 1 & 0 \\
\hline \multicolumn{4}{|l|}{ Experience as a caregiver: } \\
\hline I to 4 years & 3 & 2 & 2 \\
\hline over 4 years & 3 & I & I \\
\hline \multicolumn{4}{|l|}{ Weekly assistance } \\
\hline $0-12$ hours & 3 & 2 & 2 \\
\hline $13-20$ hours & 3 & 1 & 0 \\
\hline over 20 hours & 0 & 0 & 1 \\
\hline \multicolumn{4}{|l|}{ Type of assistance given:. } \\
\hline A.D.L & 5 & 3 & 2 \\
\hline 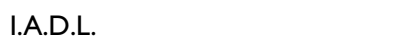 & 6 & 3 & 3 \\
\hline Psychological support & 4 & 3 & 2 \\
\hline Other(stimulation) & 3 & 3 & 0 \\
\hline
\end{tabular}

In this group of respondents, only one caregiver was interviewed individually.

\section{Physical factors}

At the development level of the DCP model's physical factors, partial and unmet needs were addressed, if succinctly, in terms of architecture, national and regional development and technology related to medical devices or assistive technology used by people with stroke.

\section{Needs related to life habits}

Table 7 presents all the themes that emerged per life habit according to the Disability Creation Process [18]. Eleven life habit areas were documented out of a possible twelve; only "Education" was not discussed. One life habit was the subject of heated discussions in all the groups: interpersonal relationships. The managers and patients in particular reported various problems persisting in relationships with friends, family members, partners, other patients and in the community. The issue of carrying out personal care at home also emerged as an unmet need and was discussed by all four groups, more especially by the health professionals. The main difficulties lie in dressing, use of the toilet, and personal hygiene. Travelling short and long distances was also reported as a widespread problem, but only by the caregivers and the patients. Eating food and maintaining a healthy body and mind were problematic life habits, mainly for the patients. The health professionals in particular underlined the persistant difficulty in carrying out leisure activities. Finally, the problem of sending and receiving messages was raised by the caregivers and health professionals, with respect to the need for more stimulation in oral and written communication. Finally, four life habits were discussed that could not be compared among the four groups: habits related to housing, taking responsibilities, community life and employment (including volunteer activities).

\section{Discussion}

The results show that partially met and unmet needs exist with respect to nine types of personal capabilities, nine environmental factors and the majority of life habits (11 out of 12). In light of these results, what conclusions can we draw from the analysis of the expressed and normative 
Table 3: Description of characteristics of health professionals

\begin{tabular}{|c|c|c|c|}
\hline Health professionals $(\mathrm{N}=25)$ & $\begin{array}{c}\text { Eastern Townships }(\mathrm{n}= \\
\text { 9) }\end{array}$ & Montreal $(n=8)$ & $\begin{array}{l}\text { Chaudières-Appalaches } \\
(\mathbf{n}=\mathbf{8})\end{array}$ \\
\hline Gender (F) & 5 & 7 & 8 \\
\hline Living environment (urban) & 7 & 8 & 8 \\
\hline \multicolumn{4}{|l|}{ Field of practice } \\
\hline Inpatient rehabilitation unit & 0 & 5 & 5 \\
\hline Acute care hospital & 2 & 3 & 1 \\
\hline Local community service centre & 4 & I & 1 \\
\hline Day centre & 2 & 0 & 0 \\
\hline Day hospital & 1 & 1 & 2 \\
\hline Community organization & 1 & 1 & 0 \\
\hline \multicolumn{4}{|l|}{ Professional discipline } \\
\hline Dietetics & 0 & 1 & 0 \\
\hline Specialized education & 1 & 0 & 1 \\
\hline Occupational therapy & 1 & I & 2 \\
\hline Nursing sciences & 0 & 1 & 2 \\
\hline Social intervention & 2 & I & 1 \\
\hline Neuropsychology & 1 & 0 & 0 \\
\hline Speech therapy & 1 & 1 & 0 \\
\hline Physiotherapy/Physical & 3 & 2 & 2 \\
\hline \multicolumn{4}{|l|}{ Rehabilitation therapy } \\
\hline Psychology & 0 & 1 & 0 \\
\hline \multicolumn{4}{|l|}{ Experience with stroke clientele } \\
\hline Less than 2 years & 0 & 0 & 2 \\
\hline $2-4$ years & 1 & 1 & 0 \\
\hline $5-8$ years & 1 & 1 & 2 \\
\hline 9 years or more & 7 & 6 & 4 \\
\hline
\end{tabular}

needs of each of the four groups of experts consulted? Furthermore, how can the results obtained improve what we currently know about the rehabilitation needs of people with stroke? Finally, what were the advantages and limitations of using the DCP model for this study?

\section{Expressed, normative and comparative needs}

Half of the expressed needs corresponded to patients' demands and were inherent to activities carrying social importance, such as feeling well, walking, having sexual relations, cooking, keeping fit, visiting friends, driving or using public transport. Few had restarted social activities outside the home. Patients interviewed individually expressed the same opinions as those participating in the focus groups. They would like more access to resources to reduce the burden on caregivers and to be more independent, but they did not mention what kind of resources, except for adapted/accessible transportation or paratransit. It is also possible that the stroke survivors did not specifically mention what kind of resources because they did not know what resources were available. Like the health care managers, they talked less about the nature and type of needs that are unmet or partially met.
The other half of the expressed needs corresponded to requests from caregivers. They said they would like more means with which to facilitate patients' integration at home and in the community. They find it hard to cope with the behavioural problems of stroke sufferers and, like the health professionals, they deplore certain shortcomings in the adjustment and rehabilitation services (Table $6, \mathrm{n}=64$ iterations) and the critical need for social assistance and education. This is probably linked to the fact that the persons they were taking care of had more serious disabilities than the patients participating in the focus groups and interviews. The caregivers, like the health professionals, talked more about what should be done and were more specific in how they perceived rehabilitation and social support services than the patients and health care managers.

Normative needs were for the most part reported by the health professionals, whose goal is to provide optimal rehabilitation services according to standard practices in the field, but who also raised concerns relating to intervention type, time restrictions, the institutional environment and the type of disability. They said they have very 
Table 4: Description of characteristics of health care managers

\begin{tabular}{|c|c|c|c|}
\hline $\begin{array}{l}\text { Health care managers }(\mathrm{N}= \\
\text { 18) }\end{array}$ & Eastern Townships $(n=7)$ & Montreal $(n=8)$ & $\begin{array}{c}\text { Chaudières-Appalaches }(n= \\
\text { 3) }\end{array}$ \\
\hline Gender (F) & 5 & 7 & 8 \\
\hline Living environment(urban) & 6 & 8 & 3 \\
\hline \multicolumn{4}{|l|}{ Field of practice: } \\
\hline Inpatient rehabilitation unit & 1 & 5 & 2 \\
\hline Acute care hospital & 1 & 2 & 0 \\
\hline Local community service centre & 1 & 1 & 1 \\
\hline Day centre & 1 & 0 & 0 \\
\hline Day hospital & 1 & 1 & 1 \\
\hline Community organization & 1 & 0 & 0 \\
\hline Rehabilitation centre & 1 & 0 & 0 \\
\hline \multicolumn{4}{|l|}{ Clientele targeted by work: } \\
\hline General & 3 & 3 & 3 \\
\hline Over 65 years & 2 & 3 & 0 \\
\hline Neurology & 2 & 2 & 0 \\
\hline \multicolumn{4}{|l|}{ Field of study: } \\
\hline Management & 3 & 4 & 1 \\
\hline Health & 6 & 7 & 3 \\
\hline \multicolumn{4}{|l|}{$\begin{array}{l}\text { Number of years' } \\
\text { management experience: }\end{array}$} \\
\hline Less than 5 years & 2 & 3 & 2 \\
\hline $5-10$ years & 1 & 1 & 1 \\
\hline More than 10 years & 4 & 4 & 0 \\
\hline
\end{tabular}

little time in which to provide the direct and indirect services necessary to ensure complete rehabilitation and to follow up on patients after hospital discharge; they therefore rely on other resources for making the adjustments needed in the home environment (Table $6, n=63$ iterations). The health professionals talked of their frustration in dedicating a large amount of time to evaluating patients and identifying rehabilitation goals but not being able to achieve all those goals. It would therefore seem that health professionals have to make intervention choices more often according to the limitations of the institutional environment in which they work, even if clinical data for their stroke patients show that some of those patients should be given more time and resources. The health professionals said they concentrate their energies on the needs of people with severe disabilities. Patients with only slight or unnoticeable disabilities receive hardly any treatment from them and are referred to other resources.

Comparative needs were mostly reported by the health care managers; they believe it is important that responsibility for patients be properly assured by the teams of pro- fessionals in charge of them. This is an attempt to standardise provision. According to the managers, the patients' needs are inextricably linked with those of their families, and in this sense, the managers heavily emphasized the need to offer more instruction to caregivers and to make more support resources available to them and to the patients when they return home. In one of the three groups of managers, the discussion revolved mainly around the availability of services rather than how accessible they were (Table 6 , medical care). They suspect that there is a trend among health professionals to want to delegate responsibility for patient care. The managers reported needs centred on means, i.e. available resources (financial, human, physical) and the demand for services for stroke patients and their caregivers (Table 6, rehabilitation). The managers were, of course, aware of the service shortages in certain disciplines (e.g.: speech therapy) and for the pressing need to find solutions for the well-being of patients, but they did not have a lot to say on the subject of making the interventions more personalized to meet the needs of patients and caregivers. Like the patients, the health care managers talked more in terms of availability of resources, and in a more global sense. 
Table 5: Partially met and unmet needs with respect to personal capabilities

\begin{tabular}{|c|c|c|c|c|c|}
\hline \multirow[t]{2}{*}{ Capabilities } & \multicolumn{4}{|c|}{ No. of iterations reported by } & \multirow[t]{2}{*}{ Themes } \\
\hline & $\begin{array}{l}\text { Caregive } \\
\text { rs }\end{array}$ & $\begin{array}{l}\text { Healt } \\
\mathrm{h} \\
\text { Profe } \\
\text { ssiona } \\
\text { ls }\end{array}$ & $\begin{array}{l}\text { Healt } \\
\text { hcare } \\
\text { Manag } \\
\text { ers }\end{array}$ & Patients & \\
\hline Intellectual capabilities & 1 & 2 & 0 & 2 & $\begin{array}{l}\text { - Stimulation (neuropsychology, speech therapy, } \\
\text { occupational therapy) }\end{array}$ \\
\hline Language capabilities & 5 & 5 & 8 & 0 & $\begin{array}{l}\text { - Aphasia: Learning to point } \\
\text { - Aphasia: Relearning words with pictures } \\
\text { - Aphasia: Relearning to write } \\
\text { - Aphasia: Communicating on the computer }\end{array}$ \\
\hline Behaviour capabilities & 33 & 8 & 1 & 7 & $\begin{array}{l}\text { - Valuing, security, acceptance, being loved, keeping } \\
\text { up to date } \\
\text { - Follow-up for depression (psychology) } \\
\text { - Follow-up for periods of mourning: agressivity, } \\
\text { revolt, frustration, discouragement, anxiety, hope } \\
\text { - Changes of role and timetable: sitting, dependence } \\
\text { on family for ADL, outings organized differently, } \\
\text { driving car }\end{array}$ \\
\hline Sense and perception capabilities & 6 & I & 1 & 0 & $\begin{array}{l}\text { - Unilateral-neglect, re-education: reading, eating, } \\
\text { dressing } \\
\text { - Hypersensitivity on affected side } \\
\text { - Spasticity } \\
\text { - Pain }\end{array}$ \\
\hline Motor activity capabilities & 3 & I & 5 & 10 & $\begin{array}{l}\text { - Learning to walk again, loss of balance, climbing } \\
\text { stairs } \\
\text { - Physical exercises, stiffness and follow-up } \\
\text { - Reeducation of upper limb and follow-up }\end{array}$ \\
\hline Digestion capabilities & 3 & 3 & 2 & 0 & $\begin{array}{l}\text { - Dysphagia, re-educating family: food and swallowing } \\
\text { - Discussion (occupational therapist, speech } \\
\text { therapist, dietician) }\end{array}$ \\
\hline Excretion capabilities & 3 & 0 & 0 & 0 & $\begin{array}{l}\text { - Enuresis: acceptance and dignity } \\
\text { - Support at day centre }\end{array}$ \\
\hline Reproduction capabilities & 2 & 3 & 0 & 10 & $\begin{array}{l}\text { - Expressing sexuality } \\
\text { - Availability of information (little discussed by health } \\
\text { professionals) }\end{array}$ \\
\hline Protection and resistance capabilities & 0 & I & I & I & $\begin{array}{l}\text { - Pain } \\
\text { - Tiredness: car driving and walking long distances }\end{array}$ \\
\hline
\end{tabular}

\section{New awareness of rehabilitation needs and contribution of needs classification}

By comparing the viewpoints of the various people involved, we can see a division between the two groups of patients/health care managers and health professionals/ caregivers. Neither the patients nor the health care managers have to give direct assistance. Patients receiving services or support are more concerned with having lost former significant occupations (e.g. in. Table 7 : Preparing food, walking long distance, driving a car), which is backed by the study of Brandiet et al. [60]. As for the managers, they are primarily concerned with the productivity of their departments: they must oversee the smooth functioning and organization of a service where patients, caregivers and health professionals meet, and they cannot deal with the individual needs of each in any detail. What the patients and the managers have in common is their concern for the how things stand at a given moment, to be able to draw a profile of the situation. It is a completely different scenario for the health care professionals and the caregivers, who have to deal with behaviour that varies from one patient to another and with the limitations imposed by the very specific needs of persons with stroke (e.g. in. Table 5 : Follow-up for periods of mourning: 
Table 6: Partially met and unmet needs with respect to environmental factors

\begin{tabular}{|c|c|c|c|c|c|}
\hline \multirow{2}{*}{$\begin{array}{l}\text { Environment } \\
\text { al Factors }\end{array}$} & \multicolumn{4}{|c|}{ No. of iterations reported by } & \multirow[t]{2}{*}{ Themes } \\
\hline & $\begin{array}{l}\text { Caregiver } \\
\mathbf{s}\end{array}$ & $\begin{array}{l}\text { Health } \\
\text { Professio } \\
\text { nals }\end{array}$ & $\begin{array}{l}\text { Healthcar } \\
\text { e } \\
\text { Managers }\end{array}$ & Patients & \\
\hline \multicolumn{6}{|l|}{$\begin{array}{l}\text { Political } \\
\text { economic } \\
\text { factors }\end{array}$} \\
\hline $\begin{array}{l}\text { Medical care } \\
\text { (socio-health } \\
\text { system) }\end{array}$ & 33 & 30 & 24 & 32 & $\begin{array}{l}\text { - Information on existing services } \\
\text { - Access to services (delays and disparities) } \\
\text { - Follow-up and transfer of files between establishments } \\
\text { - Respite services for caregivers: lodging, sitting } \\
\text { - Long-term follow-up by CLSCI } \\
\text { - Information on medication } \\
\text { - Follow-up on taking medication }\end{array}$ \\
\hline $\begin{array}{l}\text { Rehabilitation } \\
\text { (socio-health } \\
\text { system) }\end{array}$ & 64 & 63 & 17 & 39 & $\begin{array}{l}\text { Rehabilitation: } \\
\text { - Multi-disciplinary care for patients: speech therapist, neuropsychologist, psychologist, } \\
\text { nutritionist } \\
\text { - Evaluation of care dependent on budget and services offered rather than on patient's } \\
\text { needs } \\
\text { - Personalized approach: length of stay, competency of staff with respect to aphasia, } \\
\text { knowledge of patient's file, feeding, alternative therapy, intensity of interventions, services } \\
\text { limited in some disciplines (speech therapy), attitude of staff with respect to } \\
\text { overprotection, staff rotation versus counselling } \\
\text { Adjustment: } \\
\text { - Access to services (delays): assistive technology, adaptation of home and vehicle } \\
\text { - Disparities between services offered in different CLSC territories } \\
\text { - Obtaining AT and support for care process: AT for the bathroom, clamp, electric bed, } \\
\text { portable hoists, AT feeding, grab bars, emergency call button } \\
\text { - Home adaptation, support for care process: door frames, bathroom, access ramps, lift on } \\
\text { rails, stairs, exiting the home } \\
\text { - Vehicle adaptation } \\
\text { - Follow-up on attribution of AT and home adaptation } \\
\text { - Support and means to find resources in the community (social worker, doctor) } \\
\text { - Psychosocial support offered to the family at start and end of stay } \\
\text { - Meeting with family at start and end of stay }\end{array}$ \\
\hline $\begin{array}{l}\text { Social } \\
\text { assistance } \\
\text { (socio-health } \\
\text { system) }\end{array}$ & 15 & 12 & 10 & 4 & $\begin{array}{l}\text { - Information on existing services } \\
\text { - Discussion group and support for caregivers } \\
\text { - Discussion group for patients } \\
\text { - Sitting or respite services } \\
\text { - Day centre } \\
\text { - Temporary lodgings } \\
\text { - Support service for meeting with volunteers } \\
\text { - Voluntary support and partnership: life project } \\
\text { - Who does what: meetings, voluntary work, services, care... }\end{array}$ \\
\hline $\begin{array}{l}\text { Other types of } \\
\text { instruction } \\
\text { (education } \\
\text { system) }\end{array}$ & 14 & 23 & 10 & 19 & $\begin{array}{l}\text { - Direct instruction to caregivers/family by health professionals (bathroom hygiene with } \\
\text { AT, practising walking, preventing falls, medication, aphasia, exercises, state of health, } \\
\text { nutrition, feeding and nourishment, basic care such as using the toilet) } \\
\text { - Integration of caregivers/family in vivo during care interventions (gym, therapy, services } \\
\text { plan, day hospital) } \\
\text { - Prevention of falls (information meeting, video) } \\
\text { - Momentum for communicating information to patient and caregiver } \\
\text { - Education on consequences and impacts at home (preparing for return home) } \\
\text { - Education on mourning process } \\
\text { - Equip caregivers with tools to find services for the patients, answers to their questions } \\
\text { and support resources }\end{array}$ \\
\hline $\begin{array}{l}\text { Public } \\
\text { infrastructures }\end{array}$ & 4 & 2 & 3 & 10 & - Adapted/accessible transportation or paratransit \\
\hline $\begin{array}{l}\text { Community } \\
\text { organizations }\end{array}$ & I & 9 & 2 & 2 & $\begin{array}{l}\text { - Information on existing services, directories } \\
\text { - Community services for stroke survivors } \\
\text { - Transport by community organizations } \\
\text { - Promotion and education by certain community organizations relating to consequences of } \\
\text { stroke (values, attitudes) }\end{array}$ \\
\hline \multicolumn{6}{|l|}{$\begin{array}{l}\text { Sociocultural } \\
\text { factors }\end{array}$} \\
\hline Social Network & 6 & 6 & I & 7 & $\begin{array}{l}\text { - Family: availability and relationships } \\
\text { - Friends: social climate }\end{array}$ \\
\hline
\end{tabular}


Table 6: Partially met and unmet needs with respect to environmental factors (Continued)

\begin{tabular}{|c|c|c|c|c|c|}
\hline $\begin{array}{l}\text { Physical } \\
\text { factors }\end{array}$ & & & & & \\
\hline $\begin{array}{l}\text { Architecture; } \\
\text { National and } \\
\text { regional } \\
\text { development }\end{array}$ & 2 & 0 & 0 & 7 & $\begin{array}{l}\text { - Circulation space in public places (walking frame, wheelchair): sidewalks, ramps, stairs } \\
\text { - Parking spaces } \\
\text { - Rest areas: public benches } \\
\text { - Use of doors }\end{array}$ \\
\hline Technology & 0 & 2 & 2 & 6 & $\begin{array}{l}\text { - Access to mobility aids for shopping (wheelchair, walking frame, tripod cane) } \\
\text { - Access to special needs equipment (pool, treadmill, rails...) }\end{array}$ \\
\hline
\end{tabular}

I : center of local community services

agressivity, revolt, frustration, discouragement, anxiety, hope). In this respect, the needs perceived by health care professionals and caregivers are more centred on how the individual functions in his or her environment and on the intervention methods needed to optimize that person's rehabilitation and adjustment. Even though the individualized approach is seen as the key to successful rehabilitation, it is not often used, according to the health care professionals, the caregivers and the patients. Many times, the caregivers reported the lack of personalization in interventions and education. They were in no way criticizing the skills of the health care professionals, but rather their availability and the momentum behind their interventions.

\section{New awareness of rehabilitation needs and contribution of DCP model}

The partially met and unmet needs (expressed, normative) arising in the various capabilities remain similar to those that have been documented (normative needs) with regard to cognitive problems (intellectual and language capabilities) [14,47-51], perceptual problems (sense and perception, protection and resistance) [47-51,72], affective problems (behaviour) [60-62,72], and motor problems (motor activity) [14,44,45,72]. The needs reported relating to behavioural skills corroborate existing literature with respect to a noticeable decline in functional and psychosocial activities during the first four years after the inpatient rehabilitation period and the fact that a number of rehabilitation interventions have not been completed when the patient is discharged $[11,59,71,75]$. The patients and caregivers therefore expressed similar needs to those raised by the health care professionals. With respect to digestion, excretion and sexual relations (reproduction capabilities), as far as we are aware there are no points of comparison with literature on this subject.

The partially met and unmet needs that emerged with respect to environmental factors go beyond those that are already known and published in scientific journals. The importance of meeting needs such as preparing for going back home, care to be given, education, information and referral to community support resources $[5,38,43,55,60,64-67,72,83]$ are all issues raised in our study and which are reported under themes linked to the socio-health system and education system under the DCP model. In this respect, the results obtained from our 12 focus groups corroborate the literature: many patients continue to face problems of social participation and many of these intensive post-rehabilitation needs have not been met. The originality of the results of this study lies in the factors explaining the unmet rehabilitation needs. Furthermore, the partially met and unmet needs relating to environmental factors also show that they are far from optimal with respect to assuring the successful participation of patients returning home. In this respect, the financial and human resources, medical care and related services, the type of instruction given to caregivers, the support provided by community organizations, the public infrastructures offering community services and the adjustment and rehabilitation services all reveal considerable shortcomings. The themes that emerge in relation to these factors could constitute means to achieve beneficial solutions for various types of decision-makers, ranging from care services administrators to public administrators in charge of designing public spaces.

Finally, partially met and unmet needs expressed in relation to life habits are concordant with previous studies, but they are more specific than the problems identified of a functional nature (stroke and mobility) $[10,60,61]$ and psychosocial nature $[22,40,43,49,52-59,72]$. Our study identifies needs associated with eating habits, personal care, housing, travel, communication, consumption of goods and services, as well as fitness of body and mind, taking responsibilities, relationships with others, primary occupation and leisure activities. The sub-themes that emerged suggest ways towards concrete solutions for the various levels of decision-makers.

In short, the DCP model will have made it possible to highlight the partially met and unmet needs relating to environmental factors that were not mentioned in literature. This finding is hardly surprising, for most of the studies already conducted did not concentrate on elderly people's adjustment to their home environments, whether in the home or in the community. 
Table 7: Partially met and unmet needs with respect to life habits

\begin{tabular}{|c|c|c|c|c|c|}
\hline \multirow[t]{2}{*}{ Life habits } & \multicolumn{2}{|l|}{$\begin{array}{l}\text { No. of } \\
\text { iterations } \\
\text { reported by }\end{array}$} & \multirow[b]{2}{*}{$\begin{array}{l}\text { Health Care } \\
\text { Managers }\end{array}$} & \multirow[b]{2}{*}{ Patients } & \multirow[t]{2}{*}{ Themes } \\
\hline & Caregivers & $\begin{array}{l}\text { Health } \\
\text { Professionals }\end{array}$ & & & \\
\hline Nutrition & 3 & 4 & 0 & 8 & $\begin{array}{l}\text { - Preparing food } \\
\text { - Independent feeding. Feeding oneself } \\
\text { - Using kitchen utensils with one hand } \\
\text { - Meals-on-wheels service } \\
\text { - Diet to be followed } \\
\text { - Difficulty swallowing }\end{array}$ \\
\hline Fitness & 1 & 5 & 3 & 9 & $\begin{array}{l}\text { - Enrolling in a group activity requiring use of upper } \\
\text { limb } \\
\text { - Exercise program offered on discharge } \\
\text { - Changing bad habits (smoking, alcohol, eating, } \\
\text { exercise) }\end{array}$ \\
\hline Personal care & 4 & 8 & 3 & 2 & $\begin{array}{l}\text { - Dressing } \\
\text { - Use of toilet } \\
\text { - Personal hygiene }\end{array}$ \\
\hline Housing & 1 & 0 & 0 & I & - Supervision at home and safe movement \\
\hline Mobility & 8 & 0 & 0 & 8 & $\begin{array}{l}\text { - Walking long distances } \\
\text { - Driving a car, losing a license } \\
\text { - Trips outside the home with community } \\
\text { organization (volunteers) restricted to bank, doctor } \\
\text { - Adapted/accessible transportation (outings, doctor) } \\
\text { - Taxi (expensive) }\end{array}$ \\
\hline Communication & 5 & 6 & 0 & 0 & - Stimulation for communication: reading, speaking \\
\hline Responsibility & 0 & 1 & 0 & 1 & $\begin{array}{l}\text { - Change in roles: managing budget, paying bills, doing } \\
\text { personal care, going to the bank }\end{array}$ \\
\hline $\begin{array}{l}\text { Interpersonal } \\
\text { relationships }\end{array}$ & 4 & 6 & 10 & 9 & $\begin{array}{l}\text { - Visit from friends or family (movement more } \\
\text { difficult) } \\
\text { - Family relations (arguments, humiliation...) } \\
\text { - Intimate and sexual relations difficult in lodgings } \\
\text { - Relationship with partner (prevention: separation, } \\
\text { divorce) } \\
\text { - Resources for meeting people socially } \\
\text { - Relationships with other patients }\end{array}$ \\
\hline Community life & 0 & 1 & 1 & 3 & $\begin{array}{l}\text { - Going to church (spiritual life) } \\
\text { - Shopping difficult if have to walk (-) and carry bags (-) } \\
\text { - Adapted leisure activities } \\
\text { - Using banking services }\end{array}$ \\
\hline $\begin{array}{l}\text { Employment and } \\
\text { other habits }\end{array}$ & 0 & 1 & 2 & 0 & $\begin{array}{l}\text { - Social integration through leisure, adapted or regular } \\
\text { work or volunteer work: find partners outside the } \\
\text { health network }\end{array}$ \\
\hline Recreation & 2 & 8 & 1 & 3 & $\begin{array}{l}\text { - Availability of volunteers for adapted/accessible } \\
\text { transportation } \\
\text { - Open-air activities in wheelchair and adapted vehicle } \\
\text { - Community leisure activities organized through day } \\
\text { centre } \\
\text { - Seeing new areas } \\
\text { - Going on travels } \\
\text { - Using restaurants }\end{array}$ \\
\hline
\end{tabular}

Strengths and limitations of the study and future research This study presents a number of strong points with respect to trustworthiness of qualitative research. Certain strategies suggested by Krefting [80] ensure rigor without sacrificing the relevance of the qualitative research. First, to ensure the credibility (truth value) of results, it was developed by researchers in different disciplines involved in the rehabilitation of older adults and considers the views of everyone involved in the process, from the patient to the health care manager. Furthermore, the density of descriptions obtained in the various groups helps us get a clear understanding of the expressed and normative needs put forward. To ensure the transferability (applicability) of the results, the diversity of the sample sought when 
recruiting by reasoned choice as well as the description of the study area and the participants ( $\mathrm{n}=72$ including 17 patients post-stroke) is detailed enough to allow readers to make evaluations from the possible transfer of data to similar contexts. The study area included three distinct geographic regions (urban, semi-urban and rural), six different fields of practice in rehabilitation and four types of expert groups. Regarding dependability (consistency), each stage of research was documented and various cases were analyzed until a consensus was reached between the researchers. All the focus group participants received a written report summarizing the themes that had emerged in their group discussions for validation. They were then all contacted to check whether they wanted to make any changes or additions to the reports. A few minor changes were made to the summary tables following these validations with participants. The reverse-coding of the transcriptions by the research team and coding validation meetings guaranteed the reliability of the results. Finally, the use of theoretical perspectives (DCP model) for analysis means and the production of data analysis reports for the researchers made it possible to ensure confirmability (neutrality).

The limitations of this study are associated with the research design (descriptive, transversal). The results only take account of the socio-political, socio-cultural and physical environments of three regions of Quebec. Due to the size of the groups, the transferability of the data cannot be completely assured, at least for persons with stroke. Indeed, given the various possible profiles of stroke patients, it is plausible that some needs were not addressed in our study, because we did not have a sufficiently wide representation of patients. There is a certain selection bias inherent to participation in the focus groups or interviews: patients whose cognitive capabilities are more greatly affected or those who have difficulty expressing themselves could not be interviewed. Nevertheless, such patients were, in part, represented by the caregivers.

Other studies are necessary to continue validation of the needs according to the Disability Creation Process framework. The expected results of a far-reaching longitudinal study led by our group will enable us to document more precisely the various degrees and types of disabilities of people with stroke, how they carry out their life habits and the obstacles they come up against in their environment.

\section{Conclusion}

Better knowledge of the needs of people with stroke in accomplishing the activities and social roles they value is essential for improving rehabilitation services, because social participation is recognized as being the ultimate goal of rehabilitation. The presence of handicap situations in areas such as interpersonal relationships, mobility and leisure can isolate the person and foster the development of secondary disabilities if appropriate interventions are not offered. A better knowledge of rehabilitation needs and changes in them after discharge from formal services will improve coordination of these services and develop other services to address needs that are not currently being met, in the aim of maintaining the population active in social roles. In this respect, the results show that needs persist after patients are discharged, relating to nine capabilities in patients, nine environmentally related factors and eleven life habits. Close caregivers and health professionals identify more unmet needs and put the emphasis on the importance of making the rehabilitation process more personalized. The patients and health care managers have a more global vision of rehabilitation needs and put greater emphasis on available resources. To encourage better social participation of elderly people with stroke when going back at home, the study suggests that more should be done to meet the needs relating to capabilities, the patient's environment and life habits. Reducing the obstacles in the socio-politico-economic environment becomes essential for assuring a more personalized approach to rehabilitation and better instruction for caregivers.

\section{Competing interests}

The authors declare that they have no competing interests.

\section{Authors' contributions}

$\mathrm{CV}$ conceived the design of the study, participated in the data analysis, and outlined and drafted the manuscript. ID managed the database, performed the data analysis and commented the manuscript. LR conceived design the study, participated in the data analysis and commented the manuscript. JR conceived design the study, participated in the data analysis and commented the manuscript. ChV formed the focus groups and conducted the interviews, performed the data analysis and commented the manuscript. JD was the principal investigator, submitted the research protocol for its financing, conceived the design of the study and the coordination of all the research meetings, participated in the data analysis and commented the manuscript. These authors contributed equally to this work. LRT participated in the design of the present study, formed the focus groups and commented the manuscript. All authors read and approved the final manuscript.

\section{Acknowledgements}

In addition to the authors of this paper, the BRAD group is composed of Sylvie Belleville, Gina Bravo, Louise Demers, Philippe Landreville, Louisette Mercier, Nicole Paquet, Hélène Payette, Constant Rainville, Bernadette Ska and René Verreault. The BRAD group collaborated for the overall research protocol, which includes five other objectives and methods related to the rehabilitation needs of stroke clientele. This study was carried out with the financial support of the Canadian Health Research Institute (CHRI) and the 
Réseau québécois de recherche sur le vieillissement du Fonds de la recherche en santé du Québec (FRSQ). Dr. Claude Vincent holds a FRSQ salary grant and Dr. Desrosiers a CHRI salary grant. The authors would like to thank the participants for their contribution to this project and the geriatric rehabilitation services for their support.

\section{References}

I. American Heart Association Statistics Committee and Stroke Statistics Subcommittee: Heart Disease and Stroke Statistics - 2006 Update. Circulation 2006, I I 3:e85

2. U.S Department of Health and Human Service: Public Health Service Quick Reference Guide for Clinicians, no. I6, Rockville, USA 1995.

3. Kaste M, Palomäki H, Sarna S: Where and how should elderly stroke patients be treated? A randomized trial. Stroke 1995 26:249-253

4. Osberg JS, McGuinnis GE, Dejong G, Seward ML, Germaine J: Long term utilization and charges among post-rehabilitation stroke patients. Am J Phys Med Rehabil 1988, 67:66-72.

5. O'Connell B, Hanna B, Penney W, Pearce J, Owen M, Warelow P: Recovery after stroke: A qualitative perspective. J Qual Clin Practice 2001, 2 I: I20-125

6. Angeleri F, Angeleri VA, Foschi N, Giaquinto S, Nolfe G, Saginario A Signorino $M$ : Depression after a stroke: an investigation through catamnesis. J Clin Psychiatry 1997, 58:26I-265.

7. De Haan R: Measuring Quality of Life in Stroke. Stroke 1993 24:320-327.

8. Neimi ML, Laaksone R, Kotila M, Waltimo O: Quality of life, 4 years after stroke. Stroke 1988, I9:1 I01-I I07.

9. Rosemarie BK: Quality of life after Stroke. Stroke 1996, 27:|467-|472

10. Pound P, Gompertz P, Ebrahim S: A patient-centered study of the consequences of stroke. Clin Rehabil 1998, I 2:338-347.

II. Gladman JRF, Lincoln NB, Barer DH: A randomized controlled trial of domiciliary and hospital-based rehabilitation for stroke patients after discharge from hospital. I Neurol Neurosurg Psychiatry 1993, 56(9):960-966.

12. Mayo NE, Wood-Dauphinee S, Ahmed S, Gordon C, Higgins J, Mcewen S, Salbach N: Disablement following stroke. Disabil Rehabil 1999, 2 I:258-268.

13. Chuang KY, Wu SC, Ma AH, Chen YH, Wu CL: Identifying factors associated with hospital readmissions among stroke patients in Taipei. J Nurs Res 2005, 13:1 17-128.

14. Lincoln NB, Gladman JRF, Berman P, Luther A, Challen K: Rehabilitation needs of community stroke patients. Disabil Rehabil 1998, 20:457-463.

15. Edwards DF, Hahn MG, Baum CM, Perlmutter MS, Sheedy C, Dromerick AW: Screening patients with stroke for rehabilitations needs: validation of the post-stroke rehabilitation guidelines. Neurorehabil Neural Repair 2006, 20:42-48.

16. Bates B, Choi JY, Duncan PW, Glasberg J], Graham GD, Katz RC, Lamberty K, Reker D, Zorowitz R: Veterans Affairs/Department of Defense Clinical Practice Guideline for the Management of Adult Stroke Rehabilitation Care: executive summary. Stroke 2005, 36:2049-2056.

17. Fougeyrollas $\mathrm{P}$, Noreau L, Bergeron H, Cloutier R, Dion SA, St-Miche $\mathrm{G}$ : Social consequences of long term impairments and disabilities: conceptual approach and assessment of handicap. Int I Rehabil Res 1998, 21:127-141.

18. Fougeyrollas P, Cloutier R, Bergeron H, Côté J, St-Michel G: The Quebec Classification: Disability Creation Process Québec, International Network on the Disability Creation Process. National Library of Canada ISBN 2-922213-06-4; 1999.

19. Martin BJ, Yip B, Hearty M, Marletta S, Hill R: Outcome, functiona recovery and unmet needs following acute stroke. Experience of patient follow up at 6 to 9 months in a newly established stroke service. Scott Med / 2002, 47:136-137.

20. Bonita R, Solomon N, Broad JB: Prevalence of stroke and stroke related disability. Stroke 1997, 28:1898-1902.

21. Dombovy ML, Basford JR, Whisnant JP, Bergstralh EJ: Disability and use of rehabilitation services following stroke in Rochester, Minnesota, 1975-1979. Stroke 1987, 18:830-836.

22. Burton CR: Living with stroke: a phenomenological study. Adv Nurs 2000, 32:301-309.
23. Cloutier-Fischer DS: Different strokes: need for help among stroke-affected persons in British Columbia. Can J Public Health 2005, 96:22l-225.

24. Mayo NE, Wood-Dauphinee S, Côté R, Durcan L, Carlton J: Activity, participation, and quality of life 6 months poststroke. Arch Phys Med Rehabil 2002, 83: 1035-1042.

25. Liu C, Thompson AJ, Playford ED: Patient dissatisfaction: Insights into the rehabilitation process. J Neurol 2004, 25 I : I094- 1097.

26. Lebel P: Services gérontologiques et gériatriques. In Précis pratique de gériatrie Edited by: Arcand M, Hébert R. Paris/St-Hyacinthe: Edisem/Maloine; 1997.

27. Trahan L, Bélanger L, Bolduc M: Une évaluation de la prestation de services dans les C.L.S.C. et les centres hospitaliers. Pour des services de qualité aux personnes âgées en perte d'autonomie Québec: Ministère de la santé et des services sociaux; 1993.

28. Shultz AA: Identification of needs of and utilisation of resources by rural and urban elders after hospital discharge to the home. Public Health Nurs 1997, 14:28-36.

29. Bradshaw J: The concept of social need. In Planning for social welfare, issues, models and tasks Edited by: Gilbert N, Specht H. Upper Saddle River: Prentice Hall; 1977:290-296.

30. Pineault R, Daveluy C: La planification de la santé Montréal: Agence D'arc Inc; 1986.

31. Béland F: Identifying profiles of service requirements in a noninstitutionalised elderly population. I Chronic Dis 1987 , 40:5I-64.

32. Liu KPY, Chan $\mathrm{CCH}$, Chan F: Would discussion on patients' needs add value to the rehabilitation process? Int J Rehabil Res 2005, 28: I-7.

33. Williams J, Lyons B, Rowland D: Unmet long-term care needs of elderly people in the community: a review of the literature. Home Health Care Serv Q 1997, 16:93-II9.

34. Garrett $D$, Cowdell $F$ : Information needs of patients and carers following stroke. Nursing older people 2005, I 7:14-16.

35. Belciug MP: Concerns and anticipated challenges of family caregivers following participation in the neuropsychological feedback of stroke patients. Int J Rehabil Res 2006, 29:77-80.

36. Lui MHL, Mackenzie AE: Chinese elderly patients' perceptions of their rehabilitation needs following a stroke. J Adv Nurs 1999, 30:391-400.

37. Van Heugten C, Visser-Meily A, Post M, Lindeman E: Care for carers of stroke patients: evidence-based clinical practice guidelines. I Rehabil Med 2006, 38: I53-I 58

38. Tooth L, Hoffmann T: Patient Perceptions of the Quality of Information Provided in a Hospital Stroke Rehabilitation Unit. British Journal of Occupational Therapy 2004, 67: I II-II7.

39. Monaghan J, Channell K, McDowell D, Sharma AK: Improving patient and carer communication, multidisciplinary team working and goal-setting in stroke rehabilitation. Clin Rehabil 2005, 19:194-199.

40. Ministère des travaux publics et services gouvernementaux: Les défis d'une société canadienne vieillissante. 1999 et après Ottawa: Gouvernement du Canada: Ottawa; 1999.

41. Garant L: Synthèse d'un programme d'évaluation sur la réponse aux besoins de longue durée des personnes âgées ayant des limitations fonctionnelles Québec: Division planification-évaluation santé et services sociaux du ministère de la santé et services sociaux; 1994. [Collection: Études et analyses]

42. Association des hôpitaux du Québec et fédération de la réadaptation en déficience physique du Québec: Centres hospitaliers et établissements de réadaptation : partenaires pour la complémentarité des services de réadaptation. Une vision et des actions intégrées Québec: Ministère de la santé et des services sociaux; 1997

43. King RB, Semik PE: Stroke caregiving: Difficult Times, Resources Use, and Needs During the First 2 Years. J Gerontol Nurs 2006, 32:37-44

44. Heath GW, Fenton PH: Physical activities among persons with disabilities. A public health perspective. Exerc Sport Sci Rev 1997, 25:195-234.

45. Kumlien S, Axelsson K, Ljunggren G, Winblad B: Stroke patients ready for discharge from acute care: a multidimensional assessment of functions and further care. Disabil Rehabil 1999 21:31-38.

46. Boter H, Rinkel GJE, de Haan RJ: Outreach nurse support after stroke: a descriptive study on patients' and carers' needs, 
and applied nursing interventions. Clin Rehabil 2004, 18:156-163.

47. Association québécoise des personnes aphasiques: Guide d'information et de référence sur l'aphasie. S'informer pour mieux agir Québec; 1997.

48. Desmond DW, Moroney JT, Sano M, Stern Y: Recovery of cognitive function after stroke. Stroke 1996, 27:1798-1803.

49. Grimby G, Andrén E, Daving Y, Wright B: Dependence and perceived difficulty in daily activities in community living stroke survivors 2 years after stroke. A study of instrumental structures. Stroke 1998, 29:1843-1849.

50. Le Dorze G, Généreux S, Laporte D, Navennec C, Brassard C, Daigle MA, Hubert M: Les déterminants individuels et sociaux de la réinsertion professionnelle des personnes aphasiques. Rapport final (DEIP-1054) Association québécoise des personnes aphasiques (AQPA); 1998.

5I. Tatemichi TK, Desmond DW, Stern Y, Paik M, Sano M, Bagiella E: Cognitive impairment after stroke: frequency patterns, and relationship to functional abilities. JNeurol Neurosurg Psychiatry 1994, 57:202-207.

52. Bisset AF, Macduff $C$, Chesson R, Maitland J: Stroke services in general practice. Are they satisfactory? Br J Gen Pract 1997, 47:787-793.

53. Feibel JH, Springer CJ: Depression and failure to resume social activities after stroke. Arch Phys Med Rehabil 1982, 63:276-278.

54. Forer SK, Miller LS: Rehabilitation outcome: comparative analysis of different patient types. Arch Phys Med Rehabil 1980, 6I:359-365.

55. Gauthier L: Comprendre le processus de fardeau subjectif. In Master thesis Université de Sherbrooke, département de service social; 1995.

56. Koenig HG, Kuchibhatla M: Use of health services by medically ill depressed elderly patients after hospital discharge. Am J Geriatr Psychiatry 1999, 7:48-56.

57. Schmidt S, Herman LM, Koenig P, Leuze M, Monahan M, Stubbers RW: Status of stroke patients: a community assessment. Arch Phys Med Rehabil 1986, 67:99-102.

58. Viitanen M, Fugl-Meyer KS, Bernspang B, Fugl-Meyer AR: Life satisfaction in long-term survivors after stroke. Scand J Rehabil Med 1988, 20:14-24.

59. Young J, Forster A: The Bradford Community Stroke Trial: results at 6 months. $\mathrm{Br}$ Med J 1992, 304:1085-1089.

60. Brandriet LM, Lyons M, Bentley J: Perceived needs of poststroke following termination. Nurs Health Care 1994, I5:5। 4-520.

6I. Lofgren B, Nyberg L, Mattsson M, Gustafson Y: Three years after in-patient stroke rehabilitation: A follow-up study. Cerebrovasc Dis 1999, 9:163-170.

62. Soderback I, Ekholm J, Caneman G: Impairment/function and disability/activity 3 years after cerebrovascular incident or brain trauma: a rehabilitation and occupational therapy view. Int Disabil Stud 1991, 13:67-73.

63. Lewinter M, Mikkelsen S: Patients' experience of rehabilitation after stroke. Disabil Rehabil 1995, 17:3-9.

64. Pierce LL, Gordon M, Steiner V: Families dealing with stroke desire information about self-care needs. Rehabil Nurs 2004 29:14-17.

65. Zwygart-Stauffacher M, Lindquist R, Savick K: Development of health care delivery systems that are sensitive to the needs of stroke survivors and their caregivers. Nurs Adm Q 2000, 24:33-42.

66. Smith LN, Lawrence M, Kerr SM, Langhorne P, Lees KR: Informal carers' experience of caring for stroke survivors. J Adv Nurs 2004, 46:235-244.

67. Cook AM, Pierce LL, Hicks B, Steiner V: Self-care needs of caregivers dealing with stroke. J Neurosci Nurs 2006, 38:3I-36.

68. Sit JW, Wong TK, Clinton M, Li LS, Fong YM: Stroke care in the home: the impact of social support on the general health family caregivers. J Clin Nurs 2004, 13:8|6-824.

69. Grimaud O, Clappier P, Denis M, Riou F: [A qualitative study for identifying determinants of the quality of stroke patient referral.]. Rev Epidemiol Sante Publique 2005, 53:ISI2-IS2I.

70. Desnoyers D, Lagacé C: La réadaptation: tendances et perspectives. Synthèse d'une recension d'écrits Montréal: Association des hôpitaux du Québec; 1995. [Collection: La reconfiguration du réseau.]

7I. Dam M, Tonin P, Casson S, Ermani M, Pizzolato G, laia V, Battistin L: The effects of long-term rehabilitation therapy on poststroke hemiplegic patients. Stroke 1993, 24:|186-I|9|.
72. Hare R, Rogers $\mathrm{H}$, Lester H, McManus R, Mant J: What do stroke patients and their carers want from community services? Fam Pract 2006, 23:131-136.

73. Evans RL, Northwood LK: Social support needs in adjustment to stroke. Arch Phys Med Rehabil 1983, 64:61-64.

74. Widen-Holmqvist L, de Pedro-Cuesta J, Holm M, Sandstrom B, Hellblom A, Stawiarz L, Bach-y-Rita P: Stroke rehabilitation in Stockholm. Basis for late intervention in patients living at home. Scand J Rehabil Med 1993, 25:173-I8I.

75. Lindmark B, Hamrin E: A five-year follow-up of stroke survivors: motor function and activities of daily living. Clin Rehabil 1995 , 9:1-9.

76. Talbot LR, Viscogliosi C, Desrosiers J, Vincent C, Rousseau J, Robichaud L: Identification of rehabilitation needs after a stroke: an exploratory study. Health Qual Life Outcomes 2004, 2:53-61

77. Anderson S, Marlett NJ: Communication in stroke: the overlooked rehabilitation tool. Age Ageing 2004, 33:440-443.

78. Morgan DL, Krueger RA: Focus Group Kit Volume I-6. Edited by: King A. London: Sage Publications; 1998.

79. Laperrière A: Critères de scientificité des recherches qualitatives. In La recherche qualitative: Enjeux épistémologiques et méthologiques Edited by: Poupart J, Deslauriers JP, Groulx LH, Laperrière A, Mayers R, Pires AP. Montréal: Gaëtan Morin Éditeur Ltée; 1997:34I-364.

80. Krefting L: Rigor in qualitative research: The assessment of trustworthiness. Am J Occup Ther I991, 45:2 14-222.

8I. Institut de la statistique: View of Regions (Quebec). [http:// www.stat.gouv.qc.ca/regions/profils/region 00/region 00 an.htm] Acceded 2007-01-30.

82. Laboratoire d'informatique et de terminologie de la réadaptation et de l'intégration sociale du Centre François-Charon et Office de la langue française: Dictionnaire de la réadaptation. Tome I: Termes techniques d'évaluation Québec: Les publications du Québec; 1995.

83. Wilma M, Hopman WL, Verner J: Quality of life during and after inpatient stroke rehabilitation. Stroke 2003, 34:80I-805.

\section{Pre-publication history}

The pre-publication history for this paper can be accessed here:

http://www.biomedcentral.com/1471-2318/7/20/prepub
Publish with Bio Med Central and every scientist can read your work free of charge

"BioMed Central will be the most significant development for disseminating the results of biomedical research in our lifetime. "

Sir Paul Nurse, Cancer Research UK

Your research papers will be:

- available free of charge to the entire biomedical community

- peer reviewed and published immediately upon acceptance

- cited in PubMed and archived on PubMed Central

- yours - you keep the copyright
BioMedcentral 